\title{
Heavy Metals in Cassava (Manihot esculenta Crantz) Harvested from Farmlands along Highways in Owerri, Nigeria
}

\author{
Josephat Nwabueze Okereke ${ }^{1, a^{*}}$, Judith Nkeiru Nduka ${ }^{1, b}$, Ukaoma Augustina Adanma,,c \\ Odangowei Inetiminebi Ogidi ${ }^{3, d}$
}

${ }^{1}$ Department of Biotechnology, School of Biological Sciences, Federal University of Technology, Owerri, Nigeria

${ }^{2}$ Department of Biology, School of Biological Sciences, Federal University of Technology, Owerri, Nigeria

${ }^{3}$ Department of Science Laboratory Technology, Federal Polytechnic, Ekowe, Bayelsa, Nigeria

*Corresponding author

\section{A R T I C L E I N F O}

Research Article

Received : 31/05/2019

Accepted : 01/12/2019

Keywords:

Heavy Metals

Manihot esculenta

Farmlands

Highways

Owerri

\section{A B S T R A C T}

Concentrations of heavy metals $(\mathrm{Cu}, \mathrm{Pb}, \mathrm{Zn}, \mathrm{Ni}, \mathrm{Cd})$ in cassava grown on farmlands along highways in Owerri, was investigated. Cassava leaves and root samples were harvested from cassava farms along three major roads with high traffic density and another rural road that served as control location. Standard laboratory procedures to determine the concentration of these metals were adopted using Atomic Absorption Spectrophotometer. The metal concentrations in $\mathrm{mg} / \mathrm{kg}$ in cassava root showed high levels of $\mathrm{Cu}(6.29 \pm 0.0346), \mathrm{Zn}(8.49 \pm 2.243), \mathrm{Pb}(0.5267 \pm 0.3156)$ and $\mathrm{Cd}$ $(0.1167 \pm 0.0833)$. The concentrations of the heavy metals in the cassava leaves were of the order: $\mathrm{Zn}$ $>\mathrm{Cu}>\mathrm{Pb}>\mathrm{Ni}>\mathrm{Cd}$. Soil plant transfer factor values for all the metals in all the sites indicated medium accumulation. Heavy metal concentrations in soil showed significant correlation with concentrations in cassava root with no significant statistical differences in bioaccumulation of heavy metals in different parts of cassava. The overall results showed evidence of some heavy metal pollution on the soils and cassava plant.

\section{Introduction}

Cassava is important part of a human diet because it is a source of nutrient. Cassava plant constitute important functional food components by contributing carbohydrate, vitamins, iron, calcium and other nutrients which have marked health effects (Thompson and Kelly, 1990; Arai, 2002). There is an inherent tendency of plants to take up toxic substances including heavy metals that are subsequently transferred along the food chain (Singh et al., 2010). As such, heavy metal contamination in plants cannot be underestimated as food stuffs are important components of human diet. Heavy metal contamination of the food items is one of the most important aspects of food quality assurance (Wang et al., 2005; Radwan and Salama, 2006; Khan et al., 2011).

Contamination of foods by heavy metals has become a challenge for producers and consumers. The main sources of heavy metals to vegetable crops are their growth media (soil, air, nutrient solutions) from which these heavy metals are taken up by the roots or foliage (Lokeshwari and Chandrappa, 2006). Research on the mechanism of heavy metal uptake by crops or plants from contaminated soils has become of ever-increasing importance as heavy metal accumulation in crops may lead to the lowering, damage and alteration of animal or human physiological functions through the food chain (Gupta, 1995). Plants show certain reactions to the increasing of toxic elements concentration in soil, depending upon the sensitivity of plants, exposure intensity and chemical species. On lands containing metals, some plant species (metalophytes) have developed tolerance towards them, and others (hyper-accumulators), are characterized by the capacity to accumulate high quantities of metals in their tissues. Heavy metal uptake by plants grown in polluted soils has been studied at a considerable extent. All findings have shown that elevated levels of metals in soil may lead to increased uptakes by plants.

Plants grown on soils possessing enhanced metal concentration have increased metal ion content. Amusan et al. (2003) studied heavy metal uptake by plants and found that $\mathrm{Pb}$ uptake by water leaf (Talinum traingulare) and Okra (Abelmoschus esculentus) increased by $200 \%$ and $733 \%$ in leaves and by $126 \%$ on the fruit of Okra relative to the control. Jassir et al. (2005) reported elevated levels 
of heavy metals in vegetables sold in the markets at Riyadh city in Saudi Arabia due to atmospheric deposition, and recently, Sharma et al. (2008) and Zurayk et al. (2001) reported that atmospheric depositions could significantly elevate the levels of heavy metals contamination in plants. This also is synonymous with the report of Abegunde et al. (2015). However, hyper-accumulating plants have been found to accumulate heavy metals above critical levels (Brady and Weil, 1999). Lettuce is a very good bioaccumulator of heavy metals and nutrients. The differences depend on plants sensitivity, and time exposure intensity (concentration of heavy metals, cultivation length, etc.), presence or absence of nutrients and other chemical species in soil (Smical et al., 2008). The uptake of these heavy metals by plants results in bioaccumulation of these elements which according to Alloway (1996) and KabataPendias and Pendias (2011) cause a serious risk to human health when plant-based food stuff are consumed. Studies on heavy metal bioaccumulation of selected tuber crops from Ishiagu, Ebonyi State, South East, Nigeria showed different levels of lead ( $\mathrm{Pb})$, Cadmium, Chromuim Ni, Mn and $\mathrm{Zn}$ (Osuocha et al., 2014).

Centella asiatica has the potential of being used as a bio-monitoring plant for heavy metal pollution in the polluted soils (Yap et al., 2010). Heavy metals uptake in different parts of plants follows the order: roots > stems > leaves. A close positive relationship has been established between the concentrations of metal accumulated in different parts of the plant and the metal levels in the most contaminated soil. A report by Ololade and Ologundudu (2007) showed that cadmium in plants comes to a large extent from atmospheric cadmium as a result of foliar absorption or root uptake of cadmium deposited on soils. The transfer of cadmium from soil to the food chain depends on a number of additional factors, such as the type of plant, the type and $\mathrm{pH}$ of the soil, and the zinc and organic matter content of the soil. It is however imperative to note that heavy metal absorption is governed by other soil characteristics like inorganic matter (Gideoon-ogero, and Josephine, 2008)

Heavy metals contamination and bioaccumulation can lead to a reduction in cassava root length (Mbong et al., 2013). Metals such as $\mathrm{Cd}, \mathrm{Ni}, \mathrm{Pb}$, have been reported to inhibit root growth in Brassica juncea, alfalfa, and wheat (John et al., 2009). The reduction in the growth of the cassava roots was caused by the suppression of the elongation growth rate of cells, because of an irreversible inhibition exerted by the heavy metals on the proton pump responsible for the root elongation process (Aidid and Okamote, 1993). Heavy metals can as well lead to reduction in root weight of cassava and other crop plants. Also, constant application of $\mathrm{Cd}, \mathrm{Ni}$ or $\mathrm{Pb}$ can result to reduction in stem girth of cassava as stated by Padmaja et al. (1990) who further reported that the reduction of stem girth of cassava could partly be the direct consequence of the inhibition of chlorophyll synthesis, and photosynthesis by these metals. The effect of the heavy metals on cassava stem girth is dependent on the cassava variety. Furthermore, cassava leaves are also heavy metal target because it causes reduction in number of leaves as reported by Mbong et al. (2013). This has also been observed by Sandalio et al. (2001) in pea plant and John et al. (2009) in Brassica juncea $L$.

\section{Material and Methods}

Study Area: The sampling locations were chosen to span a wide range of traffic density and to give a good geographical coverage in Owerri, Imo State. Owerri consists of three Local Government Areas including Owerri Municipal, Owerri North and Owerri West. It has an estimated population of more than 401,873 as at 2006 and approximately 100 square kilometres in area. Geographic coordinates of Owerri, lies within Latitude: $5^{\circ} 29.0178^{\prime}$ North, Longitude: $7^{\circ} 1.995^{\prime}$ East. Owerri has a tropical wet climate with average temperature is $26.4^{\circ} \mathrm{C}$; sits in the rain forest, and produces many agricultural products, such as yams, cassava, corn, rubber and palm products. Some major roads that go through the city are: PortHarcourt road, Aba road, Onitsha road, and Okigwe road with other roads within the city.

\section{Sample Collection}

Samples of soil, cassava leaves and roots were randomly collected from three farmlands situated along busy roads in Owerri: Owerri-Onitsha road, OwerriPortHarcourt road and Owerri-Aba road. Control samples were collected from another cassava farmland in a rural settlement in Owerri (Oforola). Samples were collected at $0-10 \mathrm{~cm}$ depth at distance intervals of 10,15 , and 20 meters from the roadway with sterilized auger in a polythene bag. Three soil samples were taken from three points from each distance and mixed together to form composite samples.

Preparation, Digestion of Soil samples, and PreTreatment of cassava plant

Samples were air-dried and sieved through a $2 \mathrm{~mm}$ sieve to remove coarse particles before chemical analysis. Measured $0.5 \mathrm{~g}$ of air-dried ground soil was transferred into $250 \mathrm{ml}$ conical flask; $5 \mathrm{ml}$ of concentrated $\mathrm{H}_{2} \mathrm{SO}_{4}$ was added followed by $25 \mathrm{ml}$ of concentrated $\mathrm{HNO}_{3}$ acid and 5 $\mathrm{ml}$ of concentrated $\mathrm{HCl}$. The flask was heated at $200^{\circ} \mathrm{C}$ for $1 \mathrm{hr}$ in a fuming hood and then cooled to room temperature. After cooling, $20 \mathrm{ml}$ of distilled water was added and the mixture was filtered to complete the digestion. Finally, the mixture was transferred to a $50 \mathrm{ml}$ volumetric flask, filled to the mark and left to settle for at least 15 hours. The filtrate was analysed for total $\mathrm{Cu}, \mathrm{Fe}, \mathrm{Mn}, \mathrm{Pb}, \mathrm{Zn}, \mathrm{Ni}$, and Cd using Atomic Absorption Spectrometer (AA500F).

The cassava samples (roots and leaves) were washed under running water to remove dust particles. The root samples were cut to small sizes using a knife. Both the roots and leaves were air-dried and then placed in a dehydrator at $80^{\circ} \mathrm{C}$ for $2-3$ days and then dried in an oven at $100^{\circ} \mathrm{C}$. Dried samples of different parts of cassava plant were ground into fine powder $(80$ mesh $)$ using a commercial blender (TSK- WestPoint, France) and stored in polyethylene bags, until used for acid digestion.

\section{Digestion of Plant Samples}

Weighed $5 \mathrm{~g}$ of the powder was put into a $250 \mathrm{ml}$ conical flask: $5 \mathrm{ml}$ of concentrated $\mathrm{H}_{2} \mathrm{SO}_{4}$ was added followed by $25 \mathrm{ml}$ of concentrated $\mathrm{HNO}_{3}$ and $5 \mathrm{ml}$ of concentrated $\mathrm{HCl}$. The contents of the tube were heated at $200^{\circ} \mathrm{C}$ for 1 hour in a fuming hood and then cooled to room temperature. About $20 \mathrm{ml}$ of distilled was added and the 
mixture was filtered using filter paper to complete the digestion of organic matter. Lastly, the mixture was transferred to a $50 \mathrm{ml}$ volumetric flask, filled to mark, and allowed to settle for at least 15 hours. The resultant supernatant was analysed for $\mathrm{Cu}, \mathrm{Fe}, \mathrm{Mn}, \mathrm{Pb}, \mathrm{Zn}, \mathrm{Ni}$, and Cd using Atomic Absorption Spectrometer (AA500F).

\section{Transfer Factor of Metal from Soil to Plant}

Metal concentrations in the extracts of soils and plants were calculated on the basis of dry weight. The plant Transfer factor was calculated as follows:

$$
\mathrm{Tf}=\frac{\text { C plant }}{\mathrm{C} \text { soil }}
$$

Where; Tf is Transfer factor, $\mathrm{C}$ plant and $\mathrm{C}$ soil represent the heavy metal concentration in extracts of plants and soils on dry weight basis, respectively (Cui et al., 2005).

\section{Results}

Concentrations of Heavy metals in cassava plants in farmlands along Highways

The mean concentrations of heavy metals $(\mathrm{Cu}, \mathrm{Pb}, \mathrm{Zn}$, $\mathrm{Ni}, \mathrm{Cd}$,) obtained for the cassava root samples planted at 5 $\mathrm{m}, 10 \mathrm{~m}$, and $15 \mathrm{~m}$ distances from the highways, and rural farms are summarized in Table 1. The levels of heavy metals in the roots ranged between $8.49 \mathrm{mg} / \mathrm{kg}$ and 0.113 $\mathrm{mg} / \mathrm{kg}$ along Owerri-Onitsha, Owerri-PortHarcourt, and Owerri-Aba roads with $\mathrm{Zn}$ recording highest value (8.49 $\mathrm{mg} / \mathrm{kg}$ ) in samples from Owerri-Onitsha road and $\mathrm{Cd}$, the least $(0.07 \mathrm{mg} / \mathrm{kg})$ in samples from Owerri-Aba road. The heavy metal levels tended to be lower in control samples.

Figures 1a - 1e present values of different metal concentration $(\mathrm{Cu}, \mathrm{Pb}, \mathrm{Zn}, \mathrm{Ni}, \mathrm{Cd})$ in cassava samples harvested at $10 \mathrm{~m}, 15 \mathrm{~m}$, and $20 \mathrm{~m}$ distance away from the highway. The level of copper in cassava root grown along Owerri-Aba road ranged from $6.18 \mathrm{mg} / \mathrm{kg}-6.23 \mathrm{mg} / \mathrm{kg}$ while Owerri-Onitsha road recorded highest copper content $(6.33 \mathrm{mg} / \mathrm{kg})$ at $15 \mathrm{~m}$ distance. The level of $\mathrm{Pb}$ at $10 \mathrm{~m}, 15 \mathrm{~m}, 20 \mathrm{~m}$ were $0.62 \mathrm{mg} / \mathrm{kg}, 0.41 \mathrm{mg} / \mathrm{kg}$, and 0.20 $\mathrm{mg} / \mathrm{kg}$ respectively, along Owerri-Aba road while values along Owerri-Portharcourt road differed. $\mathrm{Zn}$ levels in samples from Owerri-Onitsha road were $9.82 \mathrm{mg} / \mathrm{kg}, 9.755$ $\mathrm{mg} / \mathrm{kg}$, and $5.90 \mathrm{mg} / \mathrm{kg}$, at $10 \mathrm{~m}, 15 \mathrm{~m}$, and $20 \mathrm{~m}$ respectively.

The total mean concentrations of Copper, Lead, Zinc, Nickel and Cadmium obtained from the cassava leaves samples at the four sites are presented in Table 2. The mean values of $\mathrm{Cu}$ along all the highways and control ranged between $6.31 \pm 0.02$ and $3.33 \pm 0.11 \mathrm{mg} / \mathrm{kg} ; \mathrm{Pb}, 0.95 \pm 0.39-$ $0.17 \pm 0.001 \mathrm{mg} / \mathrm{kg} ; \mathrm{Zn}, 6.26 \pm 0.58-4.03 \pm 0.13 \mathrm{mg} / \mathrm{kg} ; \mathrm{Ni}$, $0.14 \pm 0.02-0.12 \pm 0.02 \mathrm{mg} / \mathrm{kg} ; \mathrm{Cd}, 0.16 \pm 0.03-0.07 \pm 0.01$. The total metal concentration deposition on cassava leaves from $10 \mathrm{~m}, 15 \mathrm{~m}$, and $20 \mathrm{~m}$ distance at different sampling locations are presented in Figures $2 \mathrm{a}-2 \mathrm{e}$.

Transfer factor (Tf): Table 3 shows the transfer factor (Tf) of heavy metals from the soil to plants, which is the ratio of the concentration of metals in plants to the total concentration in the soil. $\mathrm{Cu}$ and $\mathrm{Zn}$ recorded high transfer factors along different sites sampled.

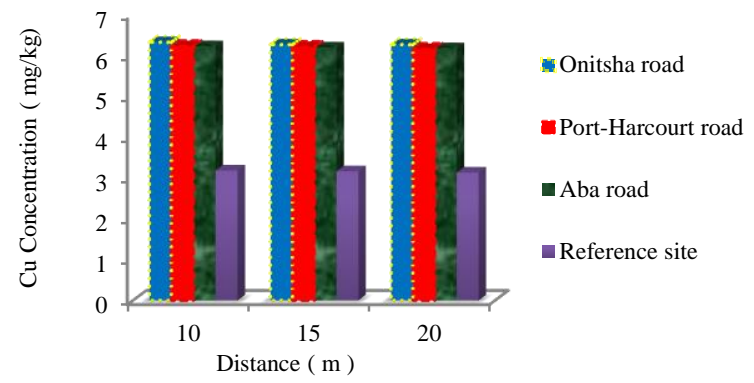

Figure 1a. Total $\mathrm{Cu}$ level in cassava root

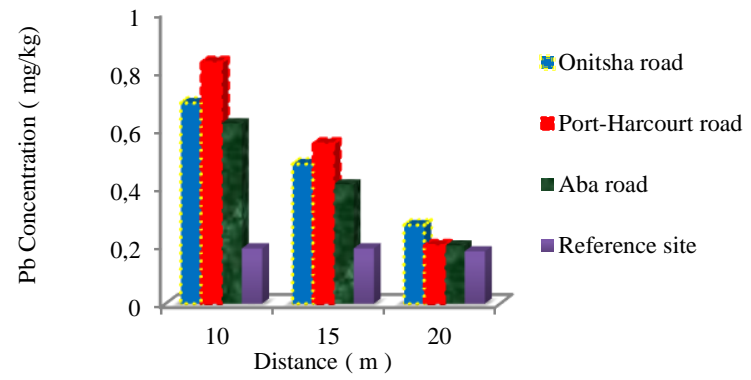

Figure 1b. Total $\mathrm{Pb}$ level in cassava root

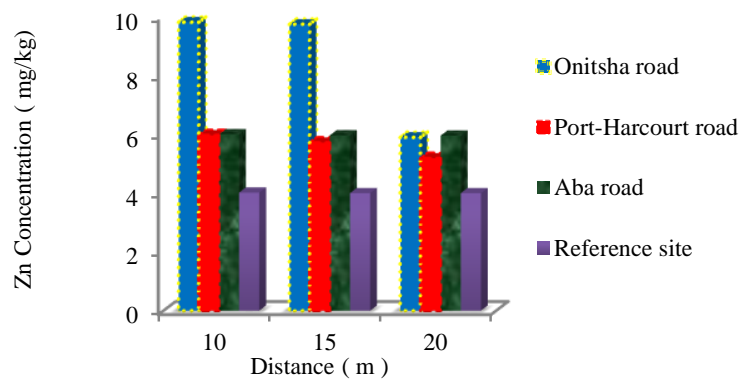

Figure 1c. Total $\mathrm{Zn}$ level in cassava root

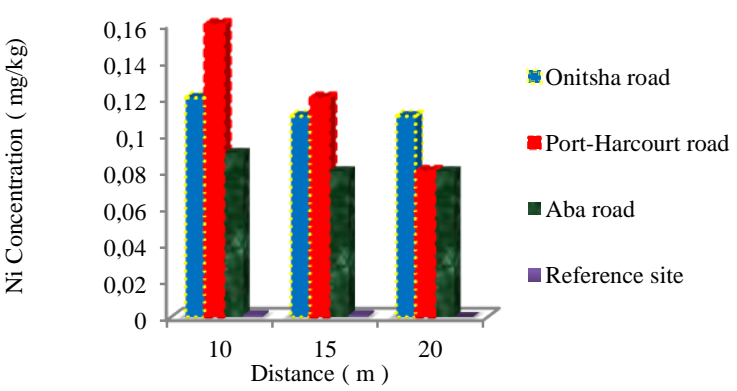

Figure 1d. Total Ni level in cassava root

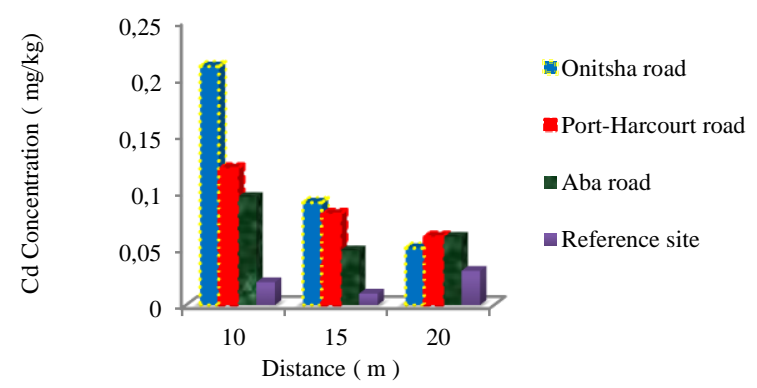

Figure 1e. Total Cd level in cassava root 
Table 1. Mean concentrations of heavy metals in cassava roots

\begin{tabular}{l|rrrr}
\hline Metal & \multicolumn{1}{|c}{ OW-NS } & OW-PH Concentrations & OW-AB $(\mathrm{mg} / \mathrm{kg})$ & \multicolumn{1}{c}{ Control } \\
\hline $\mathrm{Cu}$ & $6.29 \pm 0.0346$ & $6.2 \pm 0.0361$ & $6.2033 \pm 0.0252$ & $3.1667 \pm 0.0251$ \\
$\mathrm{~Pb}$ & $0.48 \pm 0.2100$ & $0.5267 \pm 0.3156$ & $0.41 \pm 0.2100$ & $0.1867 \pm 0.0058$ \\
$\mathrm{Zn}$ & $8.49 \pm 2.2430$ & $5.6267 \pm 0.3980$ & $5.98 \pm 0.0265$ & $4.0067 \pm 0.0115$ \\
$\mathrm{Ni}$ & $0.113 \pm 0.0058$ & $0.12 \pm 0.0400$ & $0.0833 \pm 0.0058$ & $0.0007 \pm 0.0006$ \\
$\mathrm{Cd}$ & $0.1167 \pm 0.0833$ & $0.0867 \pm 0.0306$ & $0.0677 \pm 0.0244$ & $0.02 \pm 0.0100$ \\
\hline
\end{tabular}

Legends: OW-NS = Owerri-Onitsha road, OW-PH = Owerri-PortHarcourt road, OW-AB = Owerri-Aba road

Table 2. Mean concentrations of heavy metals in cassava leaves

\begin{tabular}{l|crrr}
\hline Metal & OW-NS & OW-PH Concentrations & OW-AB (mg/kg) & \multicolumn{1}{c}{ Control } \\
\hline $\mathrm{Cu}$ & $5.90667 \pm 0.6813$ & $6.31 \pm 0.0200$ & $6.2267 \pm 0.0252$ & $3.333 \pm 0.1069$ \\
$\mathrm{~Pb}$ & $0.7833 \pm 0.2250$ & $0.95 \pm 0.3904$ & $0.713 \pm 0.2829$ & $0.1667 \pm 0.00578$ \\
$\mathrm{Zn}$ & $6.2633 \pm 0.5781$ & $5.953 \pm 0.0252$ & $5.99 \pm 0.0265$ & $4.03 \pm 0.1308$ \\
$\mathrm{Ni}$ & $0.1367 \pm 0.0058$ & $0.1333 \pm 0.0379$ & $0.1233 \pm 0.0208$ & $0.1433 \pm 0.0153$ \\
$\mathrm{Cd}$ & $0.1033 \pm 0.0153$ & $0.158 \pm 0.0327$ & $0.0763 \pm 0.0068$ & $0.0667 \pm 0.0115$ \\
\hline
\end{tabular}

Legends: OW-NS = Owerri-Onitsha road, OW-PH = Owerri-PortHarcourt road, OW-AB = Owerri-Aba road

Table 3. Plant Transfer factor (Tf) of mean of metals

\begin{tabular}{l|cccc}
\hline Metal & Onitsha Road & Ph Road & Aba Road & Referencee \\
\hline $\mathrm{Cu}$ & 0.99 & 1.03 & 0.99 & 1.06 \\
$\mathrm{~Pb}$ & 0.24 & 0.52 & 0.20 & 0.11 \\
$\mathrm{Zn}$ & 1.07 & 0.97 & 1.00 & 0.99 \\
$\mathrm{Ni}$ & 0.17 & 0.23 & 0.18 & 0.06 \\
$\mathrm{Cd}$ & 0.20 & 0.21 & 0.09 & 0.13 \\
\hline
\end{tabular}

Table 4. Mean difference in concentrations between distance and Cassava root.

\begin{tabular}{l|ccrrrr}
\hline Metal & $10-15 \mathrm{~m}$ & Sig. diff & $15-20 \mathrm{~m}$ & Sig. Diff & $10-20 \mathrm{~m}$ & Sig. diff \\
\hline $\mathrm{Cu}$ & $0.03000 \pm 020680$ & 0.197 & $0.0300 \pm 0.020683$ & 0.197 & $0.000 \pm 0.020683$ & 1.000 \\
$\mathrm{~Pb}$ & $0.05250 \pm 0.15777$ & 0.751 & $0.1900 \pm 0.157770$ & 0.274 & $0.1375 \pm 0.15777$ & 0.417 \\
$\mathrm{Zn}$ & $0.77000 \pm 0.83730$ & 0.393 & $0.92750 \pm 83730$ & 0.310 & $0.15750 \pm 0.83730$ & 0.857 \\
$\mathrm{Ni}$ & $0.01500 \pm 0.01438$ & 0.337 & $0.01975 \pm 01438$ & 0.219 & $0.00475 \pm 01438$ & 0.753 \\
$\mathrm{Cd}$ & $0.04425 \pm 0.03193$ & 0.215 & $0.00300 \pm 0.03193$ & 0.928 & $0.04125 \pm 0.03193$ & 0.244 \\
\hline
\end{tabular}

Mean \pm SEM

Table 5. Correlation between concentration of heavy metals in soil and root of Cassava crop.

\begin{tabular}{l|cc}
\hline Metal & Spearman's corr. Coefficient & Sig diff \\
\hline $\mathrm{Cu}$ & 0.632 & 0.368 \\
$\mathrm{~Pb}$ & -1.000 & 0.000 \\
$\mathrm{Zn}$ & -1.000 & 0.000 \\
$\mathrm{Ni}$ & -0.500 & 0.667 \\
$\mathrm{Cd}$ & 0.200 & 0.800 \\
\hline$\alpha=0.05$ & &
\end{tabular}

Statistical correlation of heavy metals in soil at different distance and cassava plants

The result for the mean difference in concentration of the heavy metals between distance and Cassava root showed no significant increase or decrease (Table 4), but the values showed an increasing trend from the $20 \mathrm{~m}$ region to the $10 \mathrm{~m}$ region. In determining the correlation between heavy metals in the soil and root of cassava crops, $\mathrm{Cu}, \mathrm{Ni}$ and $\mathrm{Cd}$ showed no correlation at $\alpha=0.05$ (Table 5). $\mathrm{Zn}$ showed a positive correlation while $\mathrm{Pb}$ showed a negative correlation even at $\alpha=0.001$ for both $\mathrm{Zn}$ and $\mathrm{Pb}$. This implies that increase in the concentration of $\mathrm{Zn}$ in soil causes a highly significant increase in $\mathrm{Zn}$ in the root of Cassava crop while an increase in concentration of $\mathrm{Pb}$ in soil causes significant decrease in the in the root concentration of Cassava crop.

\section{Discussion}

The levels of heavy metals bioaccumulation in cassava root and leaves reported in this study are generally lower than the WHO/FAO (2001) safe limit. There were also evidences of decrease in concentration with increase in distance at each site. Possibly due to low $\mathrm{pH}, \mathrm{Cd}$ was found to bio-accumulate in cassava roots and leaves. Several studies have reported that cadmium is a highly mobile metal, easily absorbed by plants through root surface and moves to wood tissue and transfers to upper parts (Adu et al., 2012), which is synonymous with the findings as recorded in this study. Itanna (2002) and Muhammad et al. (2008) reported that there is a direct relation between the levels of cadmium in the root zone and its absorption by plant. Thus in this study, soil Cd concentration is higher than plant $\mathrm{Cd}$ concentration. 


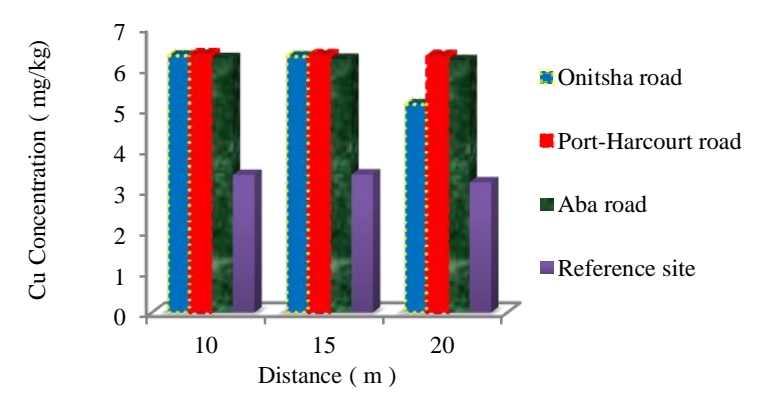

Figure 2a. Total $\mathrm{Cu}$ content in cassava leaves

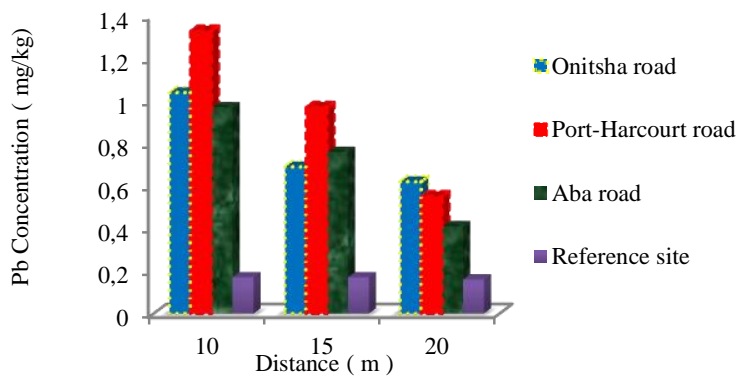

Figures 2b: Total $\mathrm{Pb}$ content in cassava leaves

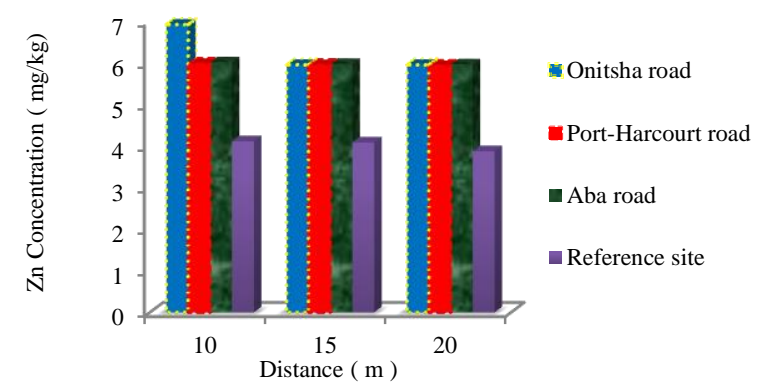

Figure 2c. Total Zn content in cassava leaves

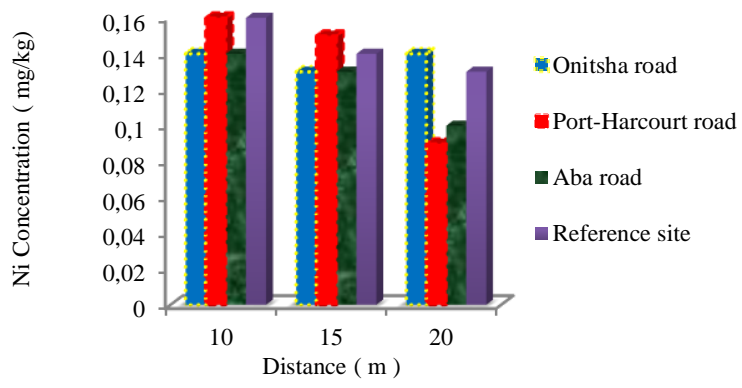

Figure 2d. Total Ni content in cassava leaves

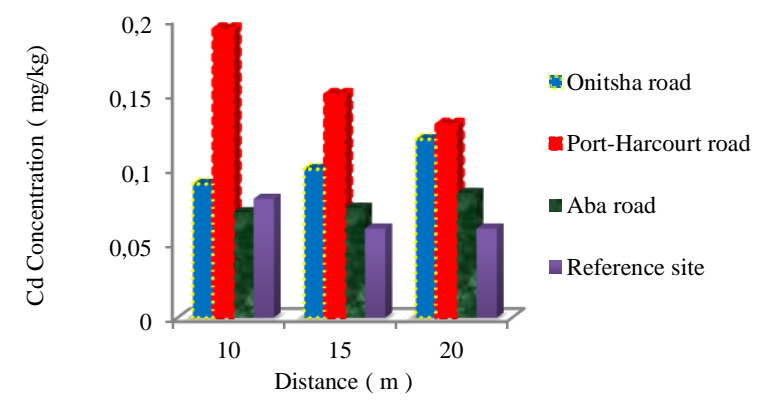

Figure 2e. Total Cd content in cassava leaves
Zinc accumulated more in cassava root $(9.82 \mathrm{mg} / \mathrm{kg})$ than the leaves which is an evidence of root mineral absorption. Chiroma et al. (2003) in their study on heavy metal contamination of vegetables and soils irrigated with sewage water in Yola, Nigeria, reported that heavy metal concentrations vary in different parts of the plant with Fe accumulating in roots and leaves while $\mathrm{Zn}$ accumulated in roots and possibly translocated gradually to the leaves. Amusan et al. (2003) studied heavy metal uptake by plants and found that $\mathrm{Pb}$ uptake by water leaf (Talinum traingulare) and Okra (Abelmoschus esculentus) increased by $200 \%$ and $733 \%$ respectively in leaves and by $126 \%$ on the fruit of Okra relative to the control. There are reports of direct relationship between levels of lead in plants and traffic density (Turan et al., 2011; Shafiq et al., 2012; Verma et al., 2013). One possible explanation for this situation is that the $\mathrm{Pb}$ uptake can be promoted by the $\mathrm{pH}$ of soil and the levels of organic matter. According to Sharma and Prasade (2010), only $3 \%$ of $\mathrm{Pb}$ in soil is translocated through the root to the shoot of plants while the rest is through foliage. The $\mathrm{Cu}$ plant concentration was highest in the root $(6.29 \pm 0.0346 \mathrm{mg} / \mathrm{kg})$ and lowest in the leaf $(3.333 \pm 0.1069 \mathrm{mg} / \mathrm{kg})$. The copper levels found in cassava plant were within safe limits in all samples. A report by Adelasoye and Ojo (2014) showed that cassava leaf contained higher concentration of the heavy metals at high traffic than low traffic density roads. In the same vein, regions closer to the roads had plant leaves higher in the metal concentrations than 20 - $30 \mathrm{~m}$ away from the roads. Muhammad et al. (2008) studied the response of three vegetables to $\mathrm{Cu}$ toxicity and found that $\mathrm{Cu}$ levels in both root and shoot increased, but root $\mathrm{Cu}$ concentration increased more sharply than shoot with increasing $\mathrm{Cu}$ levels in growth media. $\mathrm{Cu}$ mainly accumulated in roots while a small fraction (10\%) of absorbed $\mathrm{Cu}$ was transported to shoot. Moshen and Moshen (2008) found that $\mathrm{Cu}$ concentration in the shoots was significantly influenced by $\mathrm{Cu}$ concentration in soil. The statistical analysis result showed that there was no significant difference in the bioaccumulation of heavy metals in the different parts of cassava crop which implies that cassava crop is not a hyper-accumulator plant. Reports show that leafy vegetables have greater potential for accumulating heavy metals in their edible parts than grains and fruit crops, due to their higher transpiration rate (Jacob, 2010).

The values of heavy metal transfer recorded are considered high because values close to or above 1 (one) are considered high Tf values (Uwah et al., 2009). The high Tf value may be due to its weak adsorption onto the organic matter which renders it more bio-available to plants (Alloway and Ayres, 1998). Pb showed low Tf values with the highest being 0.52 , indicating that cassava plants from the study area did not have a high $\mathrm{Pb}$ contamination. From the results obtained, the highest transfer factor recorded was in $\mathrm{Zn}$, with all values above 0.5 , indicating that cassava plants were contaminated with $\mathrm{Zn}$ probably from anthropogenic sources, and this is based on the suggestion that the greater the transfer coefficient value above 0.50 , the greater the chances of plant-metal contamination (Kloke et al., 1984). Chiroma et al. (2003) showed that Zn accumulates in roots and translocates gradually to the leaves. This implies that the bioaccumulation of heavy metals in plant was very high and food processed from such 
could lead to hypertension, arthritis, diabetes, anaemia, cancer, cardiovascular disease, cirrhosis, reduced fertility; hypoglycemia, headaches, osteoporosis, kidney disease, and stroke (Lokeshappa et al., 2012) due to $\mathrm{Zn}$ poisoning. $\mathrm{Cd}$ had very low $\mathrm{Tf}$ in all the samples which is in contrast with work carried out by Mohammed and Folorunsho (2015) who recorded a mean Cd value of $3.214 \mathrm{mg} / \mathrm{kg}$. The difference may be due to location of study, considering the fact that soil from different locations differ in properties. The bioaccumulation of heavy metal in cassava root and leaves showed a mean value with no significant difference for the three locations and control. Plants are known to take up and accumulate trace metals from contaminated soil (Abdul Kasheem and Singh, 1999), hence detection in plant leaves and crop samples was not surprising. Although the levels of these metals were within normal range for plants, continual consumption could lead to accumulation and adverse health implications particularly for $\mathrm{Pb}, \mathrm{As}$, and Cd (Opaluwa, 2012). Furthermore, values obtained in soil and crop plant samples could be attributed to vehicular emission deposit on farmlands and crops.

\section{Conclusion}

The overall results showed evidence of some heavy metal pollution on the soils and bio-accumulation in cassava plants, from farmlands along highways in Owerri. The heavy metal levels tended to be lower in control samples. $\mathrm{Cu}$ and $\mathrm{Zn}$ recorded high transfer factors along different sites sampled. While $\mathrm{Zn}$ showed a positive correlation, $\mathrm{Pb}$ showed a negative correlation. This implies that increase in the concentration of $\mathrm{Zn}$ in soil causes a highly significant increase in $\mathrm{Zn}$ in the root of Cassava plant while an increase in concentration of $\mathrm{Pb}$ in soil causes significant decrease in the in the root concentration.

\section{References}

Abdul Kasheem MD, Singh B. 1999. Heavy metal contamination of soil and vegetation in the vicinity of industries in Bangladesh - Water, Air and Soil Pollution. Contamination of Vegetables in Delhi Executive Summary of Technical Report, 115: 347-361.

Abegunde SM, Agibade SA, Awonyemi IO. 2015. Assessment of heavy metal distribution and contamination in atmospheric dust from major roads in Ado- Ekiti, Ekiti State using pollution index. Turkish Journal of Agriculture-food Science and Technology, 6(9): 1196 - 1199.

Adelasoye KA, Ojo OA. 2014. Accumulation of heavy metal pollutants in soil and cassava leaf and their effects on soil microbial population on roadsides in Ogbomoso, Nigeria. International Journal of Applied Agriculture and Apiculture Research. 10:1-2.

Adu AA, Aderinola OJ, Kusemiju V. 2012. Heavy metal concentration in garden lettuce (Lactuca sativa L.) grown along Badagry expreessway, Lagos, Nigeria. Transnational Journal of Science and Technology. 2(7): 115-130

Aidid SB, Okamoto H. 1993. Responses of elongation growth rate, turgor pressure and cell wall extensibility of stem cells of Impatiens balsamina to lead, cadmium and zinc. Biometals, 6: 245-249.

Alloway BJ, Ayres DC. 1998. Chemical Principle of Environmental Pollution. Water, Air, and Soil Pollution. 102: 216-218.

Alloway BS. 1996. Heavy Metals in Soil. Halsteed press, John Wiley and Sons Inc. London: pp. 339.
Amusan A, Bada S Salami A. 2003. Effect of traffic density on heavy metal content of soil and vegetation along roadsides in Osun state, Nigeria. West African Journal of Applied Ecology 4:107-144.

Arai S. 2002. Global view on functional foods: Asian perspectives. British Journal of Nutrition, 88:139-143.

Brady NC, Weil RR. 1999. The Nature and Properties of Soils. 12th ed. Prentice - Hall Inc. New York; pp.860.

Chiroma TM, Hymore FK, Ebawele RO. 2003. Heavy Metal contamination of Vegetables and Soils irrigated with sewage water in Yola. NJER, 2(3): 25-31.

Gideon-Ogero, Josephine E. 2008. Levels of heavy metals (lead cadmium, zinc, magnesium and copper) in cassava from Niger Delta of Nigeria as an indication of soil environmental pollution. Journal of the Chemical Society, 2:120-143.

Gupta A. 1995. Heavy metal accumulation by three species of mosses in Shillong, North-Eastern India. Water, Air and Soil Pollution, 82(3-4):751-756

Itanna F. 2002. Metals in leafy vegetables grown in Addis Ababa and toxicological implications. Ethiopian Journal of Health Development, 16(3):295-302

Jacob JO. 2010. Assessment of Heavy Metals Bio-accumulation in Spinach, Jute Mallow and Tomato in farms within Kaduna Metropolis, American Journal of Analytical Chemistry, 2(1): 1346.

Jassir MS, Shaker A, Khaliq MA. 2005. Deposition of heavy metal on green leafy vegetables sold on roadsides of Riyadh city, Saudi Arabia. Bulletin of Environmental Contamination and Toxicology, 75:1020-1027.

John R, Gadgil K, Sharma G. 2009. Heavy metal toxicity: Effect on plant growth, biochemical parameters and metal accumulation by Brassica juncea L. International Journal of Plant Production, 3:66-70.

Kabata-Pendias A, Pendias H. 2011. Trace Elements in Soils and Plants. 4rd edn. CRC, New York.

Khan MN, Wasim AA, Sarwar A, Rasheed MF. 2011. Assessment of heavy metal toxicants in the roadside soil along the N-5, National Highway, Pakistan. Environmental Monitoring and Assessment, 182:587-595.

Kloke A, Sauerbeck DC, Vetter H. 1984. The contamination of plants and soils with heavy-metals and the transport of metals in terrestrial food chains. In: JO Nriagu (ed) Changing Metal Cycles and Human Health. Dahlem Konferenzen, Berlin, pp 113-141.

Lokeshappa B, Shivpuri K, Tripathi V, Dikshit AK 2012. Assessment of Toxic Metals in Agricultural Produce. Food and Public Health, 2(1): 24-29.

Lokeshwari H, Chandrappa GT. 2006. Impact of heavy metal contamination of Bellandur Lake on soil and cultivated vegetation. Current Science, 91, 622-627.

Mbong EO, Ogbemudia FO, Okon JE, Umoren UB. 2013. Evaluation of concentration of heavy metals in leaf tissues of three improved varieties of Manihot esculenta crantz. Journal of Environmental Research and Management 4(3): 02140218

Mohammed SA, Folorunsho JO. 2015. Heavy metals concentration in soil and Amaranthus retroflexus grown on irrigated farmlands in the Makera Area, Kaduna, Nigeria. Journal of Geography and Regional Planning, 8(8):210-217

Mohsen B, Mohsen S. 2008. Investigation of metal accumulation in some vegetables irrigated with waste water in Shahre Rey -Iran and Toxicological implications. Am-Euras. Journal of Agricultural and Environmental Science, 4(1):86-92.

Muhammad F, Farooq A, Umer R. 2008. Appraisal of Heavy Metal Contents in different Vegetables grown in the Vicinity of an Industrial Area. Pakistan Journal of Botany 40(5):20992106.

Ololade IA, Ologundudu A. 2007. Concentrations and bioavailability of cadmium by some plants. African Journal of Biotechnology, 6(16):1916-1921 
Opaluwa OD, Aremu M O, Ogbo LO, Abiola KA, Odiba IE, Abubakar MM, Nweze NO. 2012. Heavy metal concentrations in soils, plant leaves and crops grown around dump sites in Lafia Metropolis, Nasarawa State, Nigeria. Advances in Applied Science Research, 3 (2):780-784

Osuocha UK, Chukwu EC, Ezekwe AS, Imo C, Charles SU, Ibe C, Ikpo JC 2014. Heavy metal bioaccumulation of selected tuber crops from Ishiagu, Ebonyi State, South East, Nigeria. Journal of Biodiversity and Environmental Sciences, 5(2):136-140

Padmaja K, Prasad DD, Prasad AR. 1990. Inhibition of chlorophyll synthesis in Phaseolus vulgaris Seedlings by cadmium acetate. Photosynthetica 24:399-405.

Radwan MA, Salama AK. 2006. Market basket survey for some heavy metals in Egyptian fruits and vegetables. Food and Chemical Toxicology, 44:1273-1278.

Sandalio LM, Dalurzo HC, Gomez M, Romero- Puertas MC, delRio LA. 2001. Cadmium induced changes in the growth and oxidative metabolism of pea plants. Journal of Experimental Botany, 52, 2115-2126

Shafiq M, Iqbal, MZ, Arayne, MS, Athar M. 2012. Biomonitoring of heavy metal contamination in Pongamia pinnata and Peltophorum pterocarpum growing in the polluted environment of Karachi, Pakistan. Journal of Applied Botany and Food Quality, 85: 120-125.

Sharma RK, Agrawal M, Marshall FM. 2008. Heavy metals (Cu, $\mathrm{Cd}, \mathrm{Zn}$ and $\mathrm{Pb}$ ) contamination of vegetables in Urban India: a case Study in Varanasi. Environmental Pollution, 154:254 263.

Sharma S, Prasade FM. 2010. Accumulation of Lead and Cadmium in Soil and Vegetable Crops along Major Highways in Agra (India). Journal of Chemistry, 7(4), 11741183.

Singh A, Sharma RK, Agrawal M, Marshall FM. 2010. Risk assessment of heavy metal toxicity through contaminated vegetables from waste water irrigated area of Varanasi, India. International Society for Tropical Ecology, 51:375-387.
Smical AI, Hotea V, Oros V, Juhasz J, Pop I. 2008. Studies on transfer and bioaccumulation of heavy metals from soil into lettuce. Environmental Engineering and Management Journal, 7: 609-615

Thompson HC, Kelly WC. 1990. Vegetable Crops. New Delhi., McGraw Hill Publishing Company Ltd. Pp 45-52

Turan D, Kocahakimoglu C, Kavcar P, Gaygisiz H, Atatanir L, Turgut C, Sofuoglu SC. 2011. The use of Olive tree (Olea europaea L.) leaves as a Bio-indicator for Environmental Pollution in the province of Aydin, Turkey., Environmental Science and Pollution Research, 18(3):355-364.

Uwah EI, Ndahi NP, Ogugbuaja VO. 2009. Study of the levels of some agricultural pollutants in soils, and water leaf (talinum triangulare) obtained in Maiduguri, Nigeria. Journal of Applied Sciences in Environmental Sanitation, 4 (2):71-78.

Verma DK, Gupta AP, Dhakeray R. 2013. Bioindicators: A comparative study on uptake and accumulation of heavy metals in some plant's leaves of M.G. Road, Agra City, India. International Journal of Environmental Pollution and Solutions, 2: 37-53

Wang XL, Sato T, Xing BS, Tao S. 2005. Health risks of heavy metals to the general public in Tianjin, China via consumption of vegetables and fish. Science of the Total Environment, 350, 28-37.

WHO/FAO. 2001. Soil testing and plant analysis, Bullentin. No 38/1, Food and Agriculture Organization, Rome, Italy, pp 712.

Yap CK, Mohd-Fitr, MR, Mazyhar IY, Tan SG. 2010. Effects of metal contaminated soils on the accumulation of heavy metal in different parts of Centella asiatica: Sains Malaysia, 39: 347-352.

Zurayk R, Sukkariyah B, Baalbaki R. 2001. Common hydrophytes as bioindicators of nickel, chromium and cadmium pollution. Water. Air and Soil Pollution, 127:373288. 